\title{
BIOLOGICAL AND BIOCHEMICAL EFFECTS OF BACILLUS THURINGIENSIS, SERRATIA MARCESCENS AND TEFLUBENZURON ON COTTON LEAFWORM
}

\author{
EL-SHEIKH, T.A.A. ${ }^{1}$, HEBA S. RAFEA ${ }^{1}$, A.M. EL-AASAR ${ }^{2}$ and S. H. ALI ${ }^{2}$ \\ 1. Plant Prot. Res. Inst., ARC, Dokki, Giza, Egypt. \\ 2. Faculty of Agriculture, Ain -Shams- University, Egypt.
}

(Manuscript received 12 March 2013)

\begin{abstract}
Two biopesticides Serratia marcescens [Eubacteriales: Enterobacteria] (used at $\mathrm{MC}_{50}$, concentration caused $50 \%$ malformation )and Bacillus thuringiensis Var. kurstaki (used at $\mathrm{LC}_{50}$ ) and insect growth regulator Teflubenzuron (used at $\mathrm{LC}_{50}$ value) were used for treatment of larvae of cotton leaf worm, Spodoptera littoralis (Boisd.) . Sequential combined Effect was carried out by treating $2^{\text {nd }}$ instar larvae with $\mathrm{LC}_{50}$ value of $B$. thuringiensis or Teflubenzuron then the larvae allowed to pupate on sawdust treated with $S$. marcescens at $M_{50}$.The effect of these three agents were assessed by toxicity, fecundity, fertility , phosphatases activity and total carbohydrates. The obtained results revealed that Teflubenzuron is a potent toxin $\left(L_{50}=0.113\right.$ $\mathrm{ppm}$ ) compared to $B$. thuringiensis ( $\mathrm{LC}_{50}=165.64 \mathrm{ppm}$ ). On the other hand, the mode of action of $S$. marcescens is through malformation, the malformation concentration fifty $\left(\mathrm{MC}_{50}\right)$ is $3.09 \times 10^{8}$ colony forming unit $/ \mathrm{ml}(\mathrm{cfu} / \mathrm{ml})$. All treatments caused a significant reduction in fecundity and fertility. The sequential combined effect showed more reducing effect on the fecundity and fertility than the individual treatments. Moreover, the activity of phosphatases and total carbohydrates were significantly fluctuated during the different periods of pupal stage. The sequential combined effect of Teflubenzuron with S.marcescence caused more significant effect on alkaline phosphatase activity than the individual treatment with S.marcescence but it was somewhat similar to Teflubenzuron. Also the sequential combined effect treatment of $B$. thureinginsis with S.marcescence had more effect than the individual treatment either with S.marcescence or $B$. thureinginsis. Moreover, all treatments caused significant decreases in total carbohydrates during the pupal stage and the sequential combined effect treatments had more decreasing effect than the individual treatments. According to the obtained result, S.marcescence could be considered as a biopesticide, and become more effective when used in sequential treatment with either Teflubenzuron or $B$. thuringiensis .
\end{abstract}

Key words: Serratia marcescens,Bacillus thuringiensis Var. kurstaki. Teflubenzuron, Spodoptera littoralis, biological, biochemical aspects. 


\section{INTRODUCTION}

The cotton leafworm, Spodoptera littoralis (Boisd.) is a highly destructive insect pest. The extensive use of insecticides to control $S$. littoralis larvae has led to several problems and hazards such as development of resistance and residual effects (Frank et al., 1990). Thus, attention was directed to search for alternative control agents with new modes of action. Among these agents are insect growth regulators (IGR's) and microbial control agents. IGR's have been classified as "biorationals"to distinguish them from conventional insecticides. These compounds are selective and specific to the target pest (Metcalf et al., 1975). Moreover, they elicit their primary action on insect metabolism and ultimately affecting development and growth of the target insect. They induce morphological abnormalities as well as death of treated insects. These characteristics made them most promising as new control agents for controlling $S$. littoralis larvae. On the other hand, the bacterium $B$. thuringiensis, proved to be a highly successful weapon for fighting some agricultural pests and it offer many advantages over chemical insecticides. $B$. thuringiensis is known to be one of the most pathogenic species of bacteria, which induce larval mortality after a course of infection stages. The interest of using such agent as a microbial bioinsectcide was increased since 1970 (Dulmage and Co-operators, 1981). The bacteria of the genus Serratia are often associated with insects and have the behavior of a facultative pathogen. (Trevor et al. 2004). In general, Serratia marcescens is not pathogenic to insects when present in the digestive tract in small numbers, but once it enters the hemocoel it multiplies rapidly and causes death in one to three days (Sikorowski, 1985). Furthermore, chitinase producing bacteria $S$. marcescens caused significant physiological and morphological effects on pupal and adult stages where it caused a significant increase in the proportion of pupal mortality, adult malformation and sterility with treated moths and also affected some enzymes activity (Tolba, 2006). The objective of this work is directed to study the assessment of $S$. marcescens as an biopesticide against $S$. littoralis with comparison to $B$. thuringiensis Var. kurstaki and the insect growth regulator Teflubenzuron as a chitin synthesis inhibitor and evaluation of sequential combined effect of $S$. marcescens with either $B$. thuringiensis or Teflubenzuron for controlling $S$. littoralis.

\section{MATERIALS AND METHODS}

\section{Rearing technique}

The stock culture of the cotton leafworm, Spodoptera littoralis (Boisd.) was obtained from a laboratory strain maintained for several generations without any insecticidal or microbial pressure, in the Cotton Pest Research Dept, Plant Protection 
Research Institute, Agricultural Research Centre, Dokki, Giza. The insect was reared on castor-oil leaves, Ricinus communis, under laboratory conditions at $25 \pm 2{ }^{\circ} \mathrm{C}$ and $60 \pm 5 \%$ R.H. $2^{\text {nd }}$ and late $6^{\text {th }}$ instars larvae were used in the current work.

\section{Control agents}

\section{Biopesticide}

1.1- Protecto: It is a wettable powder formulation, based on Bacillus thuringiensis Var. kurstaki. It contains lepidopteran toxin $9.4 \%$ produced by the Plant Protection Research Institute, Agricultural Research Centre, Dokki , Giza, Egypt.

1.2- Serratia marcescens: Chitinase-producing bacterial strain belongs to Enterobactieraceae isolated from Egyptian Soils. The isolated bacterial strain was formulated as a biocontrol agent for controlling parasitic nematodes. It was produced by Soils, Water and Environ. Res. Inst. Agriculture research center, and distributed on a commercial scale (trade name, Nemaless)

\section{IGR}

Common name: Teflubenzuron.

Trade name: No moult $15 \%$ S.C.

This IGR has been obtained from Sumitomo Chemical Co., Ltd., Japan.

\section{Bioassay:}

Preliminary tests for the individual treatments were carried out using series of concentrations (in water) for each of the bio-agent, Serratia marcescens $\left(10^{5}\right.$, $10^{6}, 10^{7}, 10^{8} .10^{9}$ ) colony forming unit/ml (cfu/ml), B. thuringiensis (44.187, $88.375,176.75,352.5,705,1410 \mathrm{ppm}$ ) and the chitin synthesis inhibitor Teflubenzuron $(0.02,0.04,0.08,0.16,0.32,0.64 \mathrm{ppm})$. Sawdust was treated with each concentration of Serratia marcescens in glass jars and offered to late $6^{\text {th }}$ instar larvae to pupate on it. The offered treated sawdust was in a wettable form, while, in case of Teflubenzuron and $B$. thuringiensis, the use of leaf-dipping technique was carried out according to Abo El-Ghar et al., 1994. Castor bean leaves, $R$. communis, were dipped in each concentration then left to dry at room temperature and these were offered to the newly moulted $2^{\text {nd }}$ instar larvae. Larvae were allowed to feed for 24 hrs., then, they were provided with fresh, clean and untreated castor bean leaves until pupation. Larvae that fed on untreated castor bean leaves were used as control for Teflubenzuron and $B$. thuringiensis treatments whereas larvae kept in untreated sawdust were considered as control for Serratia marcescens. In all treatments, three replicates were carried out for each concentration, each replicate consisted of 20 larvae. The larval mortality and adult malformation percentages were determined. The data were then subjected to probit analysis (Finney, 1971) to obtain the LC $_{50}$ values of both Teflubenzuron 
and B. thuringiensis as well as the concentration which causes $50 \%$ adult malformation $\left(\mathrm{MC}_{50}\right)$ for $S$. marcescens. The sequential combined effect treatments of $S$. marcescens either with B. thuringiensis (Bt/Serr) or Teflubenzuron (Teflu /Serr)were carried out by treatment of the $2^{\text {nd }}$ instar larvae with the obtained $\mathrm{LC}_{50}$ either of B. thuringiensis or Teflubenzuron then, at the end of larval stage, the late $6^{\text {th }}$ instar larvae were allowed to pupate on sawdust treated with $S$. marcescens at the $\mathrm{MC}_{50}$.The Toxicity index of the tested compounds was determined according to Sun (1950) as follows:

$$
\text { Toxicity index }=\frac{\mathrm{LC}_{50} \text { of the most toxic compound }}{\mathrm{LC}_{50} \text { of other compounds }} \times 100
$$

\section{Biological studies:}

In all treatments, either the individual or the sequential treatments, the larvae were examined daily. The number of eggs deposited by mated female moth and the percentage of egg hatchability were recorded. Mating processes occurred according to the following combinations: Treated female $\mathrm{x}$ treated male, Treated female $\mathrm{x}$ untreated male, untreated female $x$ Treated male and untreated female $x$ untreated male (control). Each mating combination consisted of newly emerged of ratio one male to one female. Three replicates were carried out for each mating combination. Fecundity and fertility of Spodoptera littoralis moths in each treatment were determined. Fecundity was measured as the total number of eggs laid/female. The deterrent index based on the number of eggs in treatment and control assays was calculated according to Lundgren (1975) as follows:

$$
\text { Deterrent index }=\frac{A-B}{A+B} \times 100
$$

Where, $A=$ number of eggs/female in control and $B=$ number of eggs /female in treatment. The egg hatchability \% (fertility) was determined.

\section{Biochemical Analysis}

$$
\begin{aligned}
& \text { Deterrent index }=\frac{A-B}{A+B} \times 100 \\
& \text { alysis }
\end{aligned}
$$

\section{Preparation of samples for biochemical analysis:}

Pupal homogenate samples were collected after 2, 4, 6, 8, 10, 12 and 14 days of prepupation and were homogenized in distilled water using a Teflon homogenizer surrounded with a jacket of crushed ice for 3 minutes. Homogenates were centrifuged at 6000 r.p.m. for 10 minutes at $5^{\circ} \mathrm{C}$. The supernatant was divided into small aliquots $(0.5 \mathrm{ml})$ and stored at $-20^{\circ} \mathrm{C}$ until analysis. Three replicates were used for each biochemical determination. 


\section{Determination of phosphatases activity}

Acid and alkaline phosphatase activities were measured according to the method of Laufer and Schin (1971).

\section{Determination of total carbohydrates}

Total carbohydrates were determined as described by Singh and Sinha (1977).

\section{Statistical analysis}

Data were analyzed by ANOVA using SAS package.

\section{RESULTS AND DISCUSSION}

\section{Toxicological effects:}

Data in Table (1) showed the susceptibility of the $2^{\text {nd }}$ instar larvae of S.littoralis towards B.thuringiensis and Teflubenzuron compounds. The $\mathrm{LC}_{50}$ of Teflubenzuron is $0.113 \mathrm{ppm}$, whereas, it is $165.64 \mathrm{ppm}$ in case of B.thuringiensis. Based on $\mathrm{LC}_{50}$ values, it is obvious that both compounds caused considerable toxic effects against the $2^{\text {nd }}$ instar larvae of Spodoptera littoralis particularly in case of Teflubenzuron which had drastic toxic effects comparing to B.thuringiensis toxicity. On the other hand, $S$. marcescence had no toxic effects against larvae. However it has the ability to cause a high malformation percentage to Spodoptera littoralis. The concentration which causes $50 \%$ adult malformation is $3.09 \times 10^{8} \mathrm{cfu}$.

The toxicity of B.thuringiensis to $S$. littoralis larvae is due to the production of crystalline $\delta$-endotoxin (cry) protein during the sporulation stage of B.thuringiensis life cycle. On digestion by susceptible larvae, the active toxin generated from the protoxin binds to the receptors on gut epithelium. This leads to paralysis of gut and mouth parts causing death of larvae (Aronson et al. 1986). On the other hand, Teflubenzuron , a potent chitin synthesis inhibitor classified as insect growth regulator, inhibits the synthesis of chitin in larvae which have ingested it, causing the integument to become fragile, and leading to mortality during the moulting (Ascher and Nemny, 1984). S. marcescensas as chitinase producing bacteria is one of the most effective bacteria for degradation of chitin. S. marcescens chitinases may find applications as biocontrol agents against insects Brurberg et al. (2000). This might explain the high malformation percentage in S.littoralis treated with $S$. marcescens obtained in the present work.

\section{Biological effects.}

\subsection{Fecundity:}

Data in Table (2) indicated the changes in the fecundity (number of eggs laid per female) and oviposition deterrent index(OVDI)of spodoptera littoralis. The obtained results showed that, in all treatments, the highest reduction in the fecundity, together 
with the highest oviposition detterent index (OVDI) were obtained for treated female mated with treated males, followed by treated females mated with normal males. On the other hand, the highest fecundity and consequently the lowest OVDI were obtained when the males were only treated. This may indicate that the females were more sensitive to the tested compounds than the males. Moreover, in all mating combinations of all treatments, the fecundity of the resulting treated females was significantly decreased as compared to control. In The individual treatments, Teflubenzuron had higher reducing effect on the fecundity particularly for treated female mated with treated males (OVDI $=75.82$ ) than the individual treatment either with $S$. marcescence (OVDI $=41.86$ ) or $B$. thuringiensis which had the less reducing effect (OVDI $=31.47$ ). Therefore, $S$. marcescence as a biopesticide is more effective on the fecundity than $B$. thuringiensis but it less effective than Teflubenzuron . Moreover, the sequential combined effect treatments had higher reducing effect than the individual treatments where, Teflu /Serr treatment caused higher significant decreases in the fecundity of all combinations than the individual treatments with both S. marcescence and Teflubenzuron particularly for treated female mated with treated males. Also Bt/Serr treatment had reducing effect which was higher than the individual $B$. thuringiensis but it was similar to the individual treatment with $S$. marcescence. As compared to their control, it is clear that $S$. marcescence clearly enhances the reducing effect either of $B$. thuringiensis or Teflubenzuron on spodoptera littoralis fecundity.

The reduction in the fecundity of spodoptera littoralis treated with $S$. marcescens was similar to that obtained by Tolba (2006) who found that $S$. marcescens significantly reduced the fecundity of $A$. ipsilon. In addition Abd El-Hameed (1995) found a significant reduction in fecundity of the Pectinophora gossypiella after treatment with B. thuringiensis. Moreover, Abdel-Aal and Abdel-Khalek (2006) found that Teflubenzuron significantly decreased the fecundity percentage of S.littoralis especially when treated females mated with treated males.

\subsection{Fertility\%}

Data in Table (3) showed changes in the fertility\% (eggs hatchability\%) of spodoptera littoralis . the obtained results revealed that all treatments in all mating combinations cause a significant decrease in fertility of spodoptera littoralis as compared to control. The fertility followed the same pattern of that of fecundity (the lowest fertility percent was obtained in mating combinations contained treated females), emphasizing that the females were more sensitive to the tested compounds than the males. The highest reduction in fertility was obvious in case of the sequential combined effect treatment Teflu /Serr. The reduction effects in the fertility were 
follow the sequence Teflu /Serr $>$ Teflubenzuron $>$ S. marcescence $>B t /$ Serr $>B$. thuringiensis, where, the fertility reduced to $15.15,22.43,35.23,45.23$ and $57.33 \%$ when treated female mated with treated male, respectively. While, the reduction effects in the fertility were follow the sequence Teflu / Serr >Teflubenzuron $>$ Bt/Serr $>$ S. marcescence> B. thuringiensis, where, the fertility reduced to $39.55,47.70$, $55.52,59.58$ and $69.56 \%$ when treated female mated with untreated male, respectively, as compared with control (the fertility being $98.25 \%$ ). These results reflect the higher reducing effect of $S$. marcescence as a biopesticide on the fertility than $B$. thuringiensis whereas Teflubenzuron had higer reducing effect on the fertility than $B$. thuringiensis and $S$. marcescence. Also, it is clearly appeared the synergistic effects of $S$. marcescence in the sequential treatment either with Teflubenzuron or $B$. thuringiensis on the fertility of $S$. littoralis.

Desneux et al. (2007) reported that reduction in the fecundity associated with pesticides may be due to both physiological and behavioral effects. The authors suggested also that insect growth regulators such as Teflubenzuron may induce mere long-term effects on fecundity than, for example, neurotoxins. Whereas, Haseeb and Amano (2002) recorded reduction in parasitism, when Teflubenzuron investigated by Cotesia plutella adults and suggested that this insect growth regulator may affect oogenesis and the development of laid eggs. Hussein et al. (2005) proposed that Cry 3Aa protein sequestered by S.littoralis binds to ovarian cadherin-like Cry receptors and disturbs the formation of functional egg chambers. This may explain the reduction in fecundity and fertility after treatment with $B$. thuringiensis. The reduction in fecundity of S.littoralis treated with $S$. marcescence might be attributed to the high adult malformation that may prevent males to reach or identify the females for mating process. The higher reduction in the fecundity and fertility in the sequential combined effect treatments compared to the individual treatments is due to the effect of two stress factors that reflect the synergistic effect of these treatments on S.littoralis .

\section{Biochemical Effects:}

\subsection{Effects on acid and alkaline phosphatase activities:}

\subsubsection{Effects on acid phosphatase activity:}

Table (4) shows acid phosphatase activity in pupal stage of Spodoptera littoralis. The obtained results indicated that, in the individual treatments, S.marcescence as well as Teflubenzuron exhibited stimulating effect on acid phosphatase activity during pupal stage except the last two times for $S$. marcescence where the activity were reduced to $14.42 \%$ and $74.93 \%$, respectively. On the other hand, individual treatment with $B$. thureinginsis caused significant decrease in acid phosphatase activity during pupal stage except the $2^{\text {nd }}$ and $6^{\text {th }}$ day of pupation, where 
significant increases were observed in activity comparing to the control. In general, during the pupal stage, the effect of Teflubenzuron was higher than $S$. marcescence which has a higher effect than $B$. thureinginsis. In the sequential combined effect treatments, Teflu / Serr had more stimulating effect by $247.79 \%$ and $161.49 \%$ at first two times, respectively, than that of both treatments with $S$. marcescence (78.27\% and $115.48 \%$, respectively) and Teflubenzuron (134.04\% and $100.54 \%$, respectively ), whereas, it caused less effect on acid phosphatase activity at the other times of pupation than that of both individual treatments with $S$. marcescence and Teflubenzuron, as compared to control . Regarding to Bt/Serr, significant decreases during pupal stage comparing to control were found, whereas, it still less effective as comparing to treatment with $B$. thureinginsis.

\subsubsection{Effects on alkaline phosphatase activity:}

Table (5) shows changes in the alkaline phosphatase activity during pupal stage of Spodoptera littoralis .The obtained results revealed that, in the individual treatments, Significant decreases from $8^{\text {th }}$ to $12^{\text {th }}$ day of pupation were observed in case of Teflubenzuron treatment which was higher than that of $B$. thureinginsis .whereas, $S$. marcescens had less reducing effect on the alkaline phosphatase activity . also, the individual treatment with Teflubenzuron caused significant increases higher than $S$. marcescens at the first two times of pupation. In the sequential combined effect treatments, Teflu / Serr caused more effect of induction at $2^{\text {nd }}$ day than that of individual treatments either of $S$. marcescens or Teflubenzuron in addition more pronounced reduction at last three times $(-76.64 \%,-91.51 \%$ and $-86.61 \%$, respectively) than that of $S$. marcescens $(-16.14 \%,-22.17 \%$ and $-35.68 \%$, respectively ) as compared to control . Moreover, Bt/Serr behave the same trend of $S$. marcescence except that $B t /$ Serr has more significant elevation effect at $4^{\text {th }}$ and $6^{\text {th }}$ days (109.46 \% and $214.93 \%$,respectively.) as well as more reducing effect at the last three times $(-58.16 \%,-35.51 \%$, and $-59.42 \%$, respectively) than that of individual S. marcescence, as compared to control .

The results either of $S$. marcescens or Teflubenzuron were in agreement with those reported by Tolba (2006) when $A$. ipsilon pupae were treated either with $S$. marcescens or Flufenoxuron. On the other hand, the decreased activity in acid phosphatase due to $B$. thureinginsis treatment is similar to Kamel et al. (2010) who found decrease in acid phosphatase activity of Spodoptera littoralis larvae after 48hrs post-treatment with $B$. thureinginsis commercial formulations ( Agerin, Dipel $2 x$ and diprel DF ), whereas, it was increased after 120 hrs. for Agerin .

the increase in acid and alkaline phosphatase activities during the first period of pupation following treatment with $S$. marcescens may be due to the bacterial growth 
inside the insect body, this process required more energy and nutrients, so the insect increases acid and alkaline phosphatase activities to compensate the reduction in energy and in tissues development (Tolba 2006). On the other hand, the decrease in alkaline phosphatase activity might be due to the partial lysis of pupal tissues and some of these tissues were retained in the formed adult. Thus, the retention of pupal tissues was a result of the depression in the alkaline phosphatase activity that led to failure in the formation of normal healthy adults (Bassal and Ismail, 1985). Acid and alkaline phosphatases have been shown to be associated with insect development especially in relation to nutrition and egg maturation (Tsumuki and Kanehisa 1984). Acid phosphatase has received considerable attention in developmental studies because of its association with histolysis. This later process is appreciable at the metamorphic moults of holometabolous species to which Spodoptera littoralis belongs. This may explain the decrease in fecundity and fertility of these compounds and their sequential combined effects toward Spodoptera littoralis which obtained in the present study.

\subsection{Effects on Total Carbohydrate contents:}

Table (6) shows changes in total carbohydrate content in pupal stage of Spodoptera littoralis. the obtained results revealed that all treatments cause significant decreases in total carbohydrate content at all times compared to control except the individual treatment with Teflubenzuron in which there were significant increases at $2^{\text {nd }}$ and $10^{\text {th }}$ days, whereas, significant decreases were observed at the other times. The decrements for the individual treatment with $S$. marcescence were gradually pronounced with time reaching drastical decreases at $10^{\text {th }}$ and $12^{\text {th }}$ days of pupation time, which more effective either than $B$. thureinginsis at the time from $4^{\text {th }}$ to $14^{\text {th }}$ days of pupation or Teflubenzuron at $4^{\text {th }}, 6^{\text {th }}, 8^{\text {th }}, 12^{\text {th }}$ and $14^{\text {th }}$ day of pupation time. Moreover, the sequential combined effect treatment ,Bt/Serr, had higher reducing effect at all times than the individual treatment with $B$. thureinginsis and than the individual $S$. marcescence from $2^{\text {nd }}$ to $10^{\text {th }}$ days of pupation time. On the other hand, the sequential combined effect Teflu /Serr had reducing effect at $4^{\text {th }}, 6^{\text {th }}$ $, 8^{\text {th }}, 12^{\text {th }}$ and $14^{\text {th }}$ days of pupation which was higher than those of individual treatment with Teflubenzuron . Thus, it is worth to mention that all treatments contained $S$. marcescence induced more reducing effect on total carbohydrate content of $S$. littoralis pupae than those of Teflubenzuron or B. thureinginsis alone .Therefore, it could be stated that $S$. marcescence enhances the reducing effect either of Teflubenzuron or $B$. thureinginsis on the carbohydrates content of $S$. littoralis.

Similar results were reported for total soluble carbohydrate content of pupae of A. ipsilon after pupation in sawdust treated with $S$. marcescens or Flufenoxuron 
(Tolba, 2006) as well as for total soluble carbohydrate content of $6^{\text {th }}$ instar larvae of Tribolium castaneum treated with Bacillus thuringiensis (Saleem et al., 1995).

The decrease in total soluble carbohydrate content of untreated pupae could be attributed to convert it into glucose for supporting all life processes. However, the decrease in total soluble carbohydrate content of treated pupae could be attributed to metamorphic changes in pupa. During this stage, the carbohydrate content supply the body with glucose which provides an energy source for synthesis of pupa and adult tissues, especially the cuticle. Carbohydrates are necessary for the normal functioning of the male and female reproductive systems, as well as for the development of the embryo. In males, sugars form an important constituent of the reproductive glands and most of the carbohydrates of reproductive system were present in the testes. In the females system, carbohydrates are necessary for vitellogenesis and for the formation of the glycosaminoglycans present in the vitelline membrane and chorion. Vitellogenesis involves the accumulation within the oocyte of carbohydrate, lipid and protein yolk to meet the structural and metabolic needs of the developing embryo (Chippenadale, 1978).

Serratia marcescens caused a high gradual decrease in total carbohydrates in S.littoralis pupae because of their requirements to glucose as energy and carbon source for propagation and growth. This may decrease the available carbohydrates in treated insect especially glucose which plays an important role in energy supply, adult maturation (sperm and oocyte development) and builds up a new chitin(Tolba, 2006). This may explain the reduction in fecundity and fertility in the treated insect .Also, this may explain the higher reduction in the fecundity and fertility for sequential combined effect treatments than those of individual treatments either with Teflubenzuron or $B$. thureinginsis.

\section{CONCLUSION}

Finally, it could be concluded that Serratia marcescens has the potentialities to reduce population density of $S$. littoralis (fertility and fecundity). Serratia marcescens also has the ability to increase adult malformation. The obtained results also clearly revealed that the effect of $S$. marcescens on the biological aspect was higher than $B$. thureinginsis, thus, $S$. marcescens can consider a good biopesticide. Also, $S$. marcescens enhances the effect of both $B$. thureinginsis and Teflubenzuron on the biological and biochemical aspects of $S$. littoralis. Therefore, $S$. marcescens could be used either with $B$. thureinginsis or Teflubenzuron through sequential treatments as a good way for the biological control. 
Table 1. Toxicity of B.thuringiensis and teflubenzuron to spodoptera littoralis treated as $2^{\text {nd }}$ instar larvae.

\begin{tabular}{|c|c|c|c|c|c|c|}
\hline Agent & $\begin{array}{l}\mathrm{LC}_{50} \\
(\mathrm{ppm})\end{array}$ & \multicolumn{2}{|c|}{ 95\% Fiducial Limits } & Slope \pm S.E. & $X^{2}(\mathrm{df})$ & Toxicity Index \\
\hline B.thuringiensis & 165.64 & 128.21 & 208.31 & $1.59 \pm 0.12$ & $0.523(5)$ & 0.068 \\
\hline Teflubenzuron & 0.113 & 0.075 & 0.171 & $1.59 \pm 0.13$ & $9.94(5)$ & 100 \\
\hline \multicolumn{7}{|c|}{ Serratia marcescence concentration which causes $50 \%$ adult malformation to spodoptera littoralis (Boisd). } \\
\hline Agent & $\begin{array}{c}* \mathrm{MC}_{50} \\
* *(\mathrm{cfu} / \mathrm{ml})\end{array}$ & \multicolumn{2}{|c|}{ 95\% Fiducial Limits } & Slope \pm S.E. & $\mathrm{x}^{2}$ & Toxicity Index \\
\hline Serratia marcescence & $3.09 \times 10^{8}$ & $7.7 \times 10^{7}$ & $3.81 \times 10^{9}$ & $0.29 \pm 0.055$ & $0.966(4)$ & - \\
\hline
\end{tabular}

* $\mathrm{MC}_{50}$ :Concentration caused $50 \%$ adult malformation.

** (cfu) : colony forming unite . 
Table 2. Effect of $\mathrm{LC}_{50}$ of B.thuringiensis, teflubenzuron and $\mathrm{MC}_{50}$ of $S$. marcescence and their combined effect on the fecundity and oviposition deterrent index in spodoptera littoralis .

\begin{tabular}{|c|c|c|c|c|c|c|c|c|c|c|c|}
\hline \multirow{2}{*}{ Compound } & \multicolumn{2}{|c|}{ Type of mating } & \multirow{2}{*}{\multicolumn{2}{|c|}{$\begin{array}{c}* * * \\
\text { Eggs / }+\end{array}$}} & \multirow{2}{*}{$\begin{array}{r}* * \\
\text { OVDI }\end{array}$} & \multirow{2}{*}{ Compound } & \multicolumn{2}{|c|}{ Type of mating } & \multirow{2}{*}{\multicolumn{2}{|c|}{$\begin{array}{c}* * * \\
\text { Eggs / } 9\end{array}$}} & \multirow{2}{*}{ OVDI } \\
\hline & $\hat{0}$ & q & & & & & $\hat{0}$ & q & & & \\
\hline \multirow{3}{*}{ Serr. } & Treated & Untreated & 1062.67 & $\begin{array}{r}c \\
\pm \quad 36.08 \\
\end{array}$ & 22.98 & \multirow{3}{*}{ Bt / Serr. } & Treated & Untreated & 992.67 & $\begin{array}{r}c \\
\pm \quad 31.05 \\
\end{array}$ & 26.18 \\
\hline & Untreated & Treated & 910.33 & $\begin{array}{r}d \\
\pm \quad 28.86 \\
\end{array}$ & 30.16 & & Untreated & Treated & 867 & $\begin{array}{r}d \\
\pm \quad 26.49 \\
\end{array}$ & 32.36 \\
\hline & Treated & Treated & 695.33 & $\begin{array}{r}\mathrm{e} \\
\pm \quad 19.12 \\
\end{array}$ & 41.86 & & Treated & Treated & 685.33 & $\begin{array}{r}e \\
\pm \quad 24.07 \\
\end{array}$ & 42.46 \\
\hline \multirow{3}{*}{$B t$} & Treated & Untreated & 1160.33 & $\begin{array}{r}b \\
\pm \quad 34.71 \\
\end{array}$ & 18.77 & \multirow{3}{*}{ Teflu/Serr. } & Treated & Untreated & 311.33 & $\begin{array}{r}g \\
\pm \quad 10.82 \\
\end{array}$ & 68.99 \\
\hline & Untreated & Treated & 1040.33 & $\begin{array}{r}C \\
\pm \quad 28.85 \\
\end{array}$ & 23.98 & & Untreated & Treated & 164.33 & $\begin{array}{r}\text { hi } \\
\pm \quad 5.24 \\
\end{array}$ & 82.34 \\
\hline & Treated & Treated & 884.33 & $\begin{array}{r}d \\
\pm 20.72 \\
\end{array}$ & 31.47 & & Treated & Treated & 99 & $\begin{array}{r}\text { i } \\
\pm \quad 4.73 \\
\end{array}$ & 88.97 \\
\hline \multirow[b]{2}{*}{ Teflubenzuron } & Treated & Untreated & 545.67 & $\begin{array}{r}f \\
\pm \quad 16.85 \\
\end{array}$ & 51.33 & \multirow{2}{*}{ Control } & \multirow[b]{2}{*}{ Untreated } & \multirow[b]{2}{*}{ Untreated } & \multirow[b]{2}{*}{1696.7} & \multirow{2}{*}{$\begin{array}{r}a \\
\pm 44.72\end{array}$} & \multirow[b]{2}{*}{ - } \\
\hline & Untreated & Treated & 333.33 & $\begin{array}{r}9 \\
\pm \quad 9.34 \\
\end{array}$ & 67.16 & & & & & & \\
\hline LSD & \multicolumn{11}{|c|}{71.205} \\
\hline
\end{tabular}

*Means with the same letter(s) are not significantly different.

** (OVDI) : oviposition deterrent index.

$* * *$ Mean \pm SE . 
Table 3. Effect of $\mathrm{LC}_{50}$ of B.thuringiensis, teflubenzuron and $\mathrm{MC}_{50}$ of $S$. marcescence and their combined effect on the egg hatchability \% in spodoptera littoralis.

\begin{tabular}{|c|c|c|c|c|c|c|c|c|c|c|c|}
\hline \multicolumn{2}{|c|}{ Type of mating } & \multicolumn{2}{|c|}{ S. marcescence } & \multicolumn{2}{|c|}{ B. thuringiensis } & \multicolumn{2}{|c|}{ Teflubenzuron } & \multicolumn{2}{|c|}{$B T / S E R R$} & \multicolumn{2}{|c|}{ Teflu/ SERR } \\
\hline$\sigma^{2}$ & q & $\begin{array}{l}\text { Number of } \\
\text { eggs } * *\end{array}$ & $\begin{array}{c}\text { hatchibility } \\
\%\end{array}$ & $\begin{array}{l}\text { Number of } \\
\text { eggs ** }\end{array}$ & $\begin{array}{c}\text { hatchibility } \\
\%\end{array}$ & $\begin{array}{l}\text { Number of } \\
\text { eggs ** }\end{array}$ & $\begin{array}{l}\text { hatchibilit } \\
\text { y } \%\end{array}$ & $\begin{array}{l}\text { Number of } \\
\text { eggs ** }\end{array}$ & $\begin{array}{c}\text { hatchibility } \\
\%\end{array}$ & $\begin{array}{l}\text { Number of } \\
\text { eggs ** }\end{array}$ & $\begin{array}{c}\text { hatchibility } \\
\%\end{array}$ \\
\hline Treated & Untreated & $\begin{array}{c}\mathrm{C} \\
686.00 \pm \\
21.10 \\
\end{array}$ & 64.55 & $870.33^{b} \pm 21.34$ & 75.01 & $\begin{array}{c}\text { gh } \\
290.67 \pm \\
10.15\end{array}$ & 53.27 & $\begin{array}{c}d \\
597.67 \pm \\
18.70\end{array}$ & 60.21 & $\begin{array}{c}\mathrm{i} \\
147.00 \pm \\
5.70\end{array}$ & 47.22 \\
\hline Untreated & Treated & $\begin{array}{c}\mathrm{e} \\
542.33 \pm \\
15.08\end{array}$ & 59.58 & $723.67^{c} \pm 16.21$ & 69.56 & $\begin{array}{c}\mathrm{i} \\
159.00 \\
7.78\end{array}$ & 47.70 & $\begin{array}{c}f \\
481.33 \pm \\
19.62\end{array}$ & 55.52 & $\begin{array}{c}\mathrm{j} \\
65.00 \\
4.73\end{array}$ & 39.55 \\
\hline Treated & Treated & $245.00^{\mathrm{h}} \pm 6.44$ & 35.23 & $\begin{array}{c}\text { ef } \\
507.00 \pm 14.31\end{array}$ & 57.33 & $\begin{array}{c}j \mathrm{jk} \\
52.33 \pm \\
4.67\end{array}$ & 22.43 & $\begin{array}{c}9 \\
310 \pm \\
13.24 \\
\end{array}$ & 45.23 & $15.00 \stackrel{k}{ } \pm 3.22$ & 15.15 \\
\hline \multicolumn{2}{|c|}{$\begin{array}{r}\text { control } \\
\text { (Untreated X Untreated) }\end{array}$} & $\begin{array}{l}\mathrm{a} \\
1667 \stackrel{ \pm}{ \pm} 4.49\end{array}$ & 98.25 & - & - & - & - & - & - & - & - \\
\hline \multicolumn{2}{|l|}{ LSD } & \multicolumn{10}{|c|}{49.713} \\
\hline
\end{tabular}

*Means with the same letter(s) are not significantly different.

** Mean $\pm \mathrm{SE}$. 
Table 4. Changes in acid phosphatase activity in pupal stage of Spodoptera littoralis treated with Serratia marcescence at MC 50 malformation , $\mathrm{LC}_{50}$ of $B$. thureinginsis, Teflubenzuron and their combined effects.

\begin{tabular}{|c|c|c|c|c|c|c|c|c|c|c|c|}
\hline \multirow{3}{*}{$\begin{array}{l}\text { Time } \\
\text { in day }\end{array}$} & \multicolumn{11}{|c|}{ Acid phosphatase activity ( $\mu \mathrm{g}$ phenol $/ \mathrm{min} / \mathrm{g}$ body weight) $(*$ Mean $\pm \mathrm{SE})$} \\
\hline & \multicolumn{11}{|c|}{ TREATMENTS } \\
\hline & Control & $\begin{array}{c}\text { Serratia } \\
\text { marcescence }\end{array}$ & $* * \%$ & B. thureinginsis & $* * \%$ & Teflubenzuron & $* * \%$ & $\begin{array}{l}\text { B. thureinginsis / } \\
\text { Serratia } \\
\text { marcescence }\end{array}$ & $* * \%$ & $\begin{array}{c}\text { Teflubenzuron / } \\
\text { Serratia } \\
\text { marcescence }\end{array}$ & $* * \%$ \\
\hline 2 & $\begin{array}{rr}\mathrm{s} \\
11.602 \pm 0.305 \\
\end{array}$ & $\begin{array}{rr} & \mathrm{ijk} \\
20.683 \pm 0.337 \\
\end{array}$ & 78.27 & $\begin{array}{r}r q \\
17.042 \pm 0.405 \\
\end{array}$ & 46.89 & $\begin{array}{r}g \\
27.153 \quad \pm 0.983 \\
\end{array}$ & 134.04 & $\begin{array}{rr}\text { uv } \\
6.673 \pm 0.130 \\
\end{array}$ & -42.48 & $\begin{array}{rr} & d \\
40.351 & \pm 0.784 \\
\end{array}$ & 247.79 \\
\hline 4 & $\begin{array}{rr} & \mathrm{ij} \\
21.101 & \pm 0.615 \\
\end{array}$ & $\begin{array}{rr} & b \\
45.469 \quad \pm 1.303 \\
\end{array}$ & 115.48 & $\begin{array}{rr} & \mathrm{st} \\
10.060 \pm 0.196 \\
\end{array}$ & -52.32 & $\begin{array}{rr}\mathrm{C} \\
42.315 \pm 1.091 \\
\end{array}$ & 100.54 & $\begin{array}{rr}\text { op } \\
17.365 \quad \pm 0.355 \\
\end{array}$ & -17.71 & $\begin{array}{r}\mathrm{a} \\
55.176 \pm 1.330 \\
\end{array}$ & 161.49 \\
\hline 6 & $\begin{array}{rr} & \mathrm{st} \\
10.999 & \pm 0.155 \\
\end{array}$ & $\begin{array}{rr} & \mathrm{g} \\
26.867 \quad \pm 0.721 \\
\end{array}$ & 144.27 & $\begin{array}{rr} & \text { nop } \\
17.517 & \pm 0.524 \\
\end{array}$ & 59.26 & $\begin{array}{rr} & h \\
23.823 & \pm 0.456 \\
\end{array}$ & 116.59 & $\begin{array}{rr} & p q \\
16.318 & \pm 0.443 \\
\end{array}$ & 48.36 & $\begin{array}{rr} & \operatorname{Imn} \\
19.054 \quad \pm 0.510 \\
\end{array}$ & 73.23 \\
\hline 8 & $\begin{array}{rr} & \mathrm{jklm} \\
20.451 & \pm 0.342 \\
\end{array}$ & $\begin{array}{rr}\mathrm{g} \\
26.182 \pm 0.704 \\
\end{array}$ & 28.02 & $\begin{array}{rr} & \mathrm{st} \\
10.274 \quad \pm 0.152 \\
\end{array}$ & -49.76 & $\begin{array}{rr}\mathrm{e} \\
35.316 \pm 0.643 \\
\end{array}$ & 72.69 & $\begin{array}{rr}\text { op } \\
17.429 \pm 0.259 \\
\end{array}$ & -14.78 & $\begin{array}{rr} & \mathrm{klm} \\
19.300 & \pm 0.297 \\
\end{array}$ & -5.63 \\
\hline 10 & $\begin{array}{rr} & \mathrm{pq} \\
16.963 & \pm 0.403\end{array}$ & $\begin{array}{rr} & \operatorname{Imn} \\
19.020 & \pm 0.288 \\
\end{array}$ & 12.13 & $\begin{array}{rr}r & r \\
13.331 & \pm 0.252\end{array}$ & -21.41 & $\begin{array}{rr}\mathrm{g} \\
25.758 \pm 0.335\end{array}$ & 51.85 & $\begin{array}{rr} & \text { op } \\
17.433 & \pm 0.272 \\
\end{array}$ & 2.77 & $\begin{array}{rr} & \text { st } \\
10.582 \pm 0.126\end{array}$ & -37.62 \\
\hline 12 & $22.092 \pm 0.541$ & $\begin{array}{rr} & \mathrm{mno} \\
18.907 & \pm 0.421 \\
\end{array}$ & -14.42 & $\begin{array}{r}p q \\
16.692 \pm 0.349 \\
\end{array}$ & -24.44 & $\begin{array}{rr} & d \\
39.996 & \pm 0.746 \\
\end{array}$ & 81.04 & $\begin{array}{rr}\mathrm{t} \\
9.487 \pm 0.212 \\
\end{array}$ & -57.06 & $\begin{array}{rr}j \mathrm{jklm} \\
19.602 \pm 0.349 \\
\end{array}$ & -11.27 \\
\hline 14 & $\begin{array}{rr} & \mathrm{Jkl} \\
20.501 & \pm 0.626 \\
\end{array}$ & $\begin{array}{rr}v \\
5.139 \pm 0.076 \\
\end{array}$ & -74.93 & $\begin{array}{r}\mathrm{u} \\
7.866 \pm 0.118 \\
\end{array}$ & -61.63 & $\begin{array}{rr}f \\
29.166 \pm 0.679 \\
\end{array}$ & 42.27 & $\begin{array}{rr} & q \\
15.555 \pm 0.358 \\
\end{array}$ & -24.13 & $\begin{array}{rr}r & r \\
13.858 & \pm 0.185 \\
\end{array}$ & -32.40 \\
\hline LSD & & & & & & 1.5456 & & & & & \\
\hline
\end{tabular}

* Means with the same letter(s) are not significantly different.

** The reduction and induction percentage in the enzyme activity with compared to control. 
Table 5. Changes in Alkaline phosphatase activity in pupal stage of Spodoptera littoralis treated with Serratia marcescence at MC $C_{50}$, LC 50 of $B$ thureinginsis, Teflubenzuron and their combined effects.

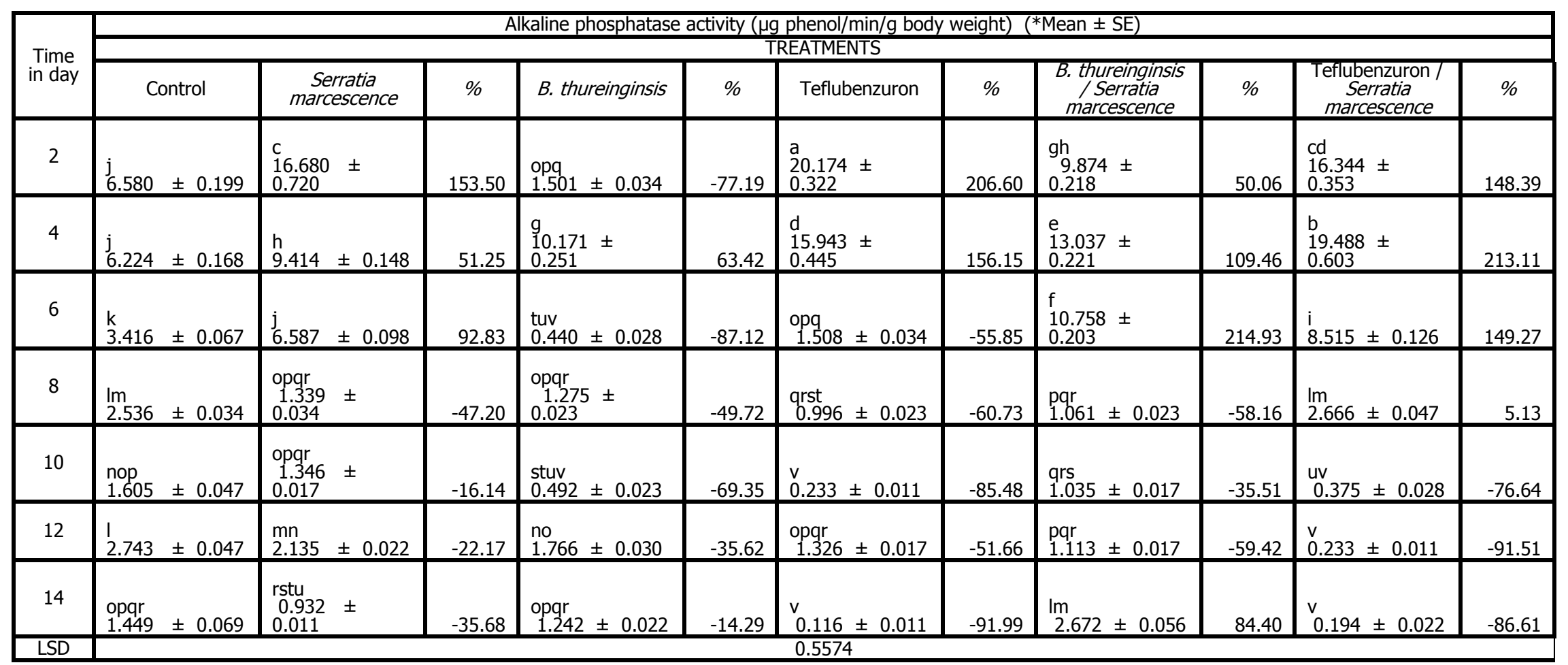

*Means with the same letter(s) are not significantly different.

** The reduction and induction percentage in the enzyme activity with compared to control . 
Table 6. Changes in total carbohydrates in pupal stage of Spodoptera littoralis treated with Serratia marcescence at MC ${ }_{50}, \mathrm{LC}_{50}$ of $B$. thureinginsis, Teflubenzuron and their combined effects.

\begin{tabular}{|c|c|c|c|c|c|c|c|c|c|c|c|}
\hline \multirow{3}{*}{$\begin{array}{l}\text { Time } \\
\text { in day }\end{array}$} & \multicolumn{11}{|c|}{ Total carbohydrates content ( $\mu$ g glucose/g body weight) $\quad(*$ Mean $\pm \mathrm{SE})$} \\
\hline & \multicolumn{11}{|c|}{ TREATMENTS } \\
\hline & Control & $\begin{array}{c}\text { Serratia } \\
\text { marcescence }\end{array}$ & $\%$ & B. thureinginsis & $\%$ & Teflubenzuron & $\%$ & $\begin{array}{l}\text { B. thureinginsis } \\
\text { / Serratia } \\
\text { marcescence }\end{array}$ & $\%$ & $\begin{array}{c}\text { Teflubenzuron / } \\
\text { Serratia } \\
\text { marcescence }\end{array}$ & $\%$ \\
\hline 2 & $\begin{array}{r}c \\
36.634 \pm 0.905\end{array}$ & $\begin{array}{r}\mathrm{e} \\
26.522 \pm 0.862 \\
\end{array}$ & -27.60 & $\begin{array}{r}\text { ghi } \\
22.898 \pm 0.843 \\
\end{array}$ & -37.50 & $\begin{array}{r}a \\
45.590 \pm 1.271\end{array}$ & 24.45 & $\begin{array}{r}\mathrm{kl} \\
19.635 \pm 0.669\end{array}$ & -46.40 & $\begin{array}{r}\mathrm{fg} \\
24.424 \pm 0.703\end{array}$ & -33.33 \\
\hline 4 & $\begin{array}{r}d \\
30.169 \pm 0.596\end{array}$ & $\begin{array}{r}j k \\
20.514 \pm 0.522 \\
\end{array}$ & -32.00 & $\begin{array}{r}\mathrm{d} \\
31.289 \pm 1.423 \\
\end{array}$ & 3.71 & $\begin{array}{r}\text { efg } \\
24.615 \pm 0.776 \\
\end{array}$ & -18.41 & $\begin{array}{r}\mathrm{mn} \\
16.037 \pm 0.562 \\
\end{array}$ & -46.84 & $\begin{array}{r}j \mathrm{jk} \\
20.673 \pm 0.577 \\
\end{array}$ & -31.48 \\
\hline 6 & $\begin{array}{r}\mathrm{C} \\
36.138 \pm 0.700 \\
\end{array}$ & $\begin{array}{r}\text { ij } \\
21.633 \pm 0.623 \\
\end{array}$ & -40.14 & $\begin{array}{r}d \\
30.178 \pm 0.876\end{array}$ & -16.49 & $\begin{array}{r}\text { hij } \\
22.300 \pm 0.689\end{array}$ & -38.29 & $\begin{array}{r}\text { no } \\
15.080 \pm 0.480\end{array}$ & -58.27 & $\begin{array}{r}\mathrm{Im} \\
17.907 \pm 0.583\end{array}$ & -50.45 \\
\hline 8 & $\begin{array}{r}a \\
45.708 \pm 0.983 \\
\end{array}$ & $\begin{array}{r}j \mathrm{jk} \\
20.440 \pm 0.607\end{array}$ & -55.28 & $\begin{array}{r}\text { ijk } \\
21.445 \pm 1.220 \\
\end{array}$ & -53.08 & $\begin{array}{r}\text { ef } \\
26.183 \pm 0.710\end{array}$ & -42.72 & $\begin{array}{r}\text { pqr } \\
11.451 \pm 0.381\end{array}$ & -74.95 & $18.141 \pm 0.504$ & -60.31 \\
\hline 10 & $\begin{array}{r}c \\
37.191 \pm 0.759 \\
\end{array}$ & $\begin{array}{r}\mathrm{t} \\
7.092 \pm 0.224 \\
\end{array}$ & -80.93 & $\begin{array}{r}\mathrm{fg} \\
24.350 \pm 0.927 \\
\end{array}$ & -34.53 & $\begin{array}{r}b \\
42.113 \pm 1.069 \\
\end{array}$ & 13.23 & $\begin{array}{r}t \\
6.653 \pm 0.278 \\
\end{array}$ & -82.11 & $\begin{array}{r}\text { ijk } \\
21.395 \pm 0.489 \\
\end{array}$ & -42.47 \\
\hline 12 & $\begin{array}{r}d \\
30.886 \pm 0.627 \\
\end{array}$ & $\begin{array}{r}\text { tu } \\
5.693 \pm 0.198 \\
\end{array}$ & -81.57 & $\begin{array}{r}\text { gh } \\
24.077 \pm 0.783 \\
\end{array}$ & -22.05 & $\begin{array}{r}\text { gh } \\
24.182 \pm 0.942 \\
\end{array}$ & -21.71 & $\begin{array}{r}\text { qrs } \\
10.423 \pm 0.329 \\
\end{array}$ & -66.25 & $\begin{array}{r}n \\
15.364 \pm 0.243 \\
\end{array}$ & -50.26 \\
\hline 14 & $\begin{array}{r}\mathrm{kl} \\
19.612 \pm 0.378 \\
\end{array}$ & $\begin{array}{r}u \\
4.098 \pm 0.098 \\
\end{array}$ & -79.10 & $\begin{array}{r}p q \\
11.669 \pm 0.434 \\
\end{array}$ & -40.50 & $\begin{array}{r}\text { op } \\
13.257 \pm 0.520 \\
\end{array}$ & -32.40 & $\begin{array}{r}r \mathrm{rs} \\
9.539 \pm 0.374 \\
\end{array}$ & -51.36 & $\begin{array}{r}\mathrm{S} \\
9.268 \pm 0.166 \\
\end{array}$ & -52.74 \\
\hline LSD & & & & & & 1.9851 & & & & & \\
\hline
\end{tabular}

*Means with the same letter(s) are not significantly different.

** The reduction and induction percentage in the enzyme activity with compared to control. 


\section{REFERENCES}

1. Abdel-Aal, A. E. and Abdel-khalek, Azza A. 2006. Effect of insect growth regulators on some biological and physiological aspects of Spodoptera littoralis (Boisd.). Bull.ent.Egypt,Econ. Ser., 32,2006 (101-112).

2. Abd El-Hameed, N. F. 1995. Evaluation of the efficacy of some bacterial preparations in controlling the pink bollworm. M.Sc. Thesis, Fac. Agric., Moshtohor (Benha Branch), Zagazig Univ., Egypt, pp: 113-120.

3. Abo El-Ghar, G. E. S., M. S. Khalil and T. M. Eid. 1994. Effect of plant extracts on development and fecundity of Agrotis ipsilon (Lepidoptera : Noctuidae). Bull. ent. Soc. Egypt, Econ. Ser., 21: 171-190.

4. Aronson, A.I., W. Beckman and P. Dunn. 1986. Bacillus thuringiensis and related insect pathogens. Microbial. Rev.50, 1-24.

5. Ascher, K.R.S. , N.E. Nemny. 1984. The effect of CME 134 on Spodoptera littoralis eggs and larvae. Phytoparasitica 12: 13-27.

6. Bassal, T. T. M. and I. E. Ismail. 1985. Acid and alkaline phosphatases of normal and juvenilized Spodoptera littoralis (Noctuidae, Lepidoptera) during metamorphosis. Proc. Zoll. Soc. Egypt, 9: 249-256.

7. Brurberg, M. B., I. F. Nes and V. G. Eijsink. 2000. Comparative studies of chitinases A and B from Serratia marcescens. Microbiology, Jul, 142 (7): 15811589.

8. Chippenadale, G. M. 1978. The function of carbohydrates in insect life processes.

9. Biochemistry of insects. (Edited by Rockstein, M.) pp. 2-54. Academic press, New York, San Francisco, London.

10. Desneux, N. , A. Decourtye and J. M. Delpuech. 2007. The sublethal effects of pesticides on beneficial arthropods. Annu. Rev. Entomol. 52: 81-106.

11. Dulmage,T. H. and Co-operators. 1981. Insecticidal activity of isolates of Bacillus thuringiensis and their potential for pest control. In "Microbial Control of Pests and Plant Diseases 1970 - 1980." (H.D. Burges, ed.). pp. 193 -223. Academic Press, London and New York .

12. Finney, D. J. 1971. Probit Analysis, A statistical treatment of the sigmoid response curve. 7th Ed., Cambridge Univ. Press, Cambridge, England.

13. Frank, R., H. E. Braun, B. D. Ripley and B. S. Clegy. 1990. Contamination of rural ponds with pesticides, 1971-1985. Ontario, Canada Bull. Environm.Contamin. Toxicology. 13: 771-817.

14. Haseeb, M. and H. Amano. 2002. Effects of contact, oral and persistent toxicity of selected pesticides on Cotesia plutellae (Hym., Braconidae), a potential parasitoid of plutella xylostella (Lep., plutellidae). J. Appl. Entomol.126: 8-13.

15. Hussein, H.M., O. Habuštová, and F. Sehnal. 2005. Beetle-specific Bacillus thuringiensis Cry3Aa toxin reduces larval growth and curbs reproduction in 
Spodoptera littoralis (Boisd.). Pest Manag Sci , 61: 1186-1192. DOI: 10.1002/ps.1112.

16. Kamel, S.A., F.A. Abd-El Aziz and M.N. El-Bakry. 2010. Biochemical effects of three commercial formulations of Bacillus thuringiensis (Agerrin, Dipel 2X and Dipel DF) on Spodoptera littoralis larvae . Egypt. Acad . J . biolog. Sci.,3 (1): 2129.

17. Laufer, H. and K. S. Schin. 1971. Quantitative studies of hydrolytic enzymes activity in the salivary gland of Chironomus tentans (Diptera :Chironomidae) during metamorphosis. Can. Entomol., 103: 454-457.

18. Lundgren, L. 1975. Natural plant chemicals acting as oviposition deterrents on cabbage butterflies, Pieris brassicae (L.) P. rapa (L.) and P. napi (L.). Zoll. ser., 4: 250 - 258.

19. Metcalf, F., P. I. Lu. and S. Bowlus. 1975. Degradation and environmental fate of 1-(2,6-diflubenzoyl)-3-(4-chlorophenyl) urea. J. Agric. Food Chem., 23: 359364.

20. Saleem, M. A., N. Tufail and A. R. Shakoori. 1995. Synergistic effect of synthetic pyrethroids on the toxicity of Bacillus thuringiensis as shown by the biochemical changes in the sixth instar larvae of Tribolium castaneum. Pakistan J. Zool., 27: (4), 317-323.

21. Sikorowski, P. P. 1985. Pecan weevil pathology, pp. 87-101. In W. W. Neel (ed.) Pecan weevil: research perspective. Quail Ridge Press, Jackson, MS.

22. Singh, N. B. and R. N. Sinha. 1977. Carbohydrates, lipids and proteins in the developmental stages of Sitophilus oryzae and S. granaries (Coleoptera: Curculionidae). Ann. Entomol. Soc. Amer., 70: 107-111.

23. Sun, Y. P. 1950. Toxicity index-An improved method of comparing the relative toxicity of insecticides. J. Econ. Entomol., 43: 45-53.

24. Tolba, H . I. 2006. Biochemical studies on Serratia marcescens for controlling the black cutworm, Agrotis ipsilon (Huf.) Ph. D. Thesis, Faculty of Agriculture, Cairo University, Egypt. pp. 57-72.

25. Trevor, A. J., R. M. Mark and M. Dharmadasa. 2004. Use of Serratia spp. bacteria for monitoring behaviour of parasitoids. International J. Pest Manage. 50 (3): 173 $-176$.

26. Tsumuki, H. and K. Kanehisa. 1984. Phosphatases in the rice stem borer, Chilo supperssalis (Walker) (Lepidoptera: Pyralidae): Some properties and changes of the activities during hibernation. Cryobiology, 21: 177-182. 


\title{
التأثير ات البيولوجية و البيوكيميائية لبكتيريا باسلليس ثيورينجينسيز و سير اثيا

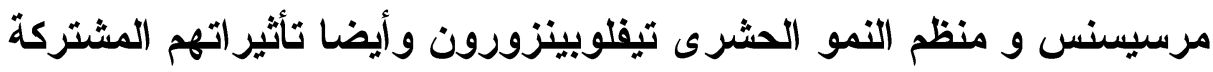 المتعاقبة ضد دودة ورق القطن سبودويتبيرا ليتوراليس (بويذد.)
}

\author{
طارق عفيفي عبد الحميد الثيخ ، هبة سمير رافع ، \\ عبد المنعم محمد الاعسر، صفوت حسن علي علي

$$
\text { r - معه بحوث وقاية النباتات - مركز البحوث الزرراعية الدقي الجيزة }
$$

الشتمل البحث على دراسة بعض التأثيرات البيولوجيه و البيوكيميائيه الناتجه عن استخدام التركيز المتسبب فى نشوه •0\% من الفراشات لبكتيريا سير اشيا مرسيسنس المعامل بها فى التربه و التركيز القاتل للنصف لكلا من المستحضر التجارى بروتيكتو (بكتيريا باسلليس ثيورينجينسيز)

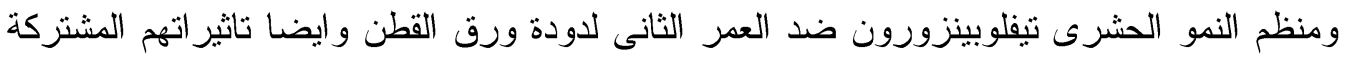
من خلال معاملة العمر الثانى بالتزكيز القاتل للنصف لكلا من الباسلليس ثيورينجينسيز

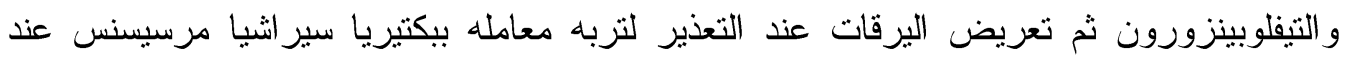

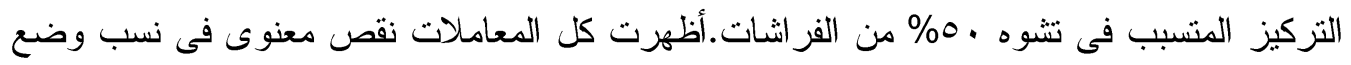

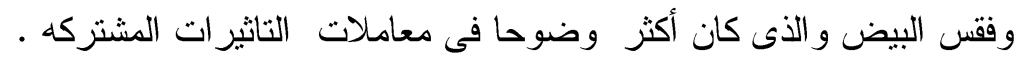

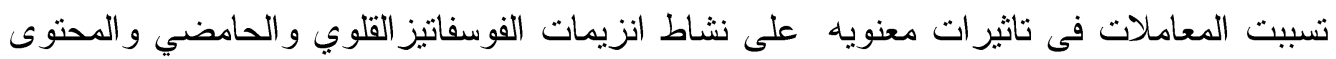

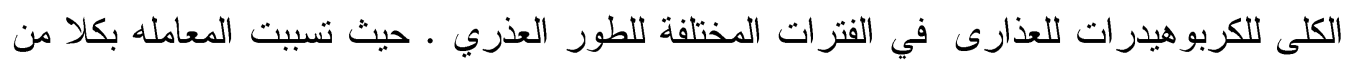
التيفلوبينزورون و السبر اشيا مرسيسنس الى زيادة نشاط إنزيم الفوسفاتيز الحامضي على مدار فترات

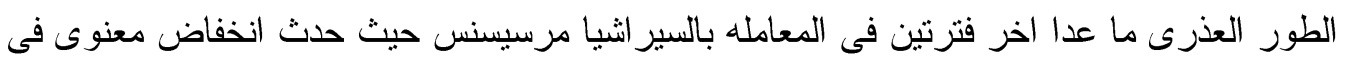

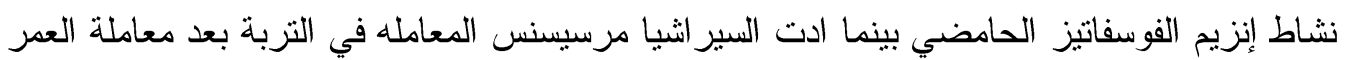

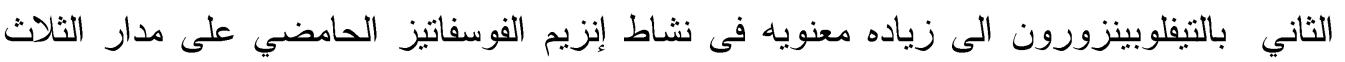

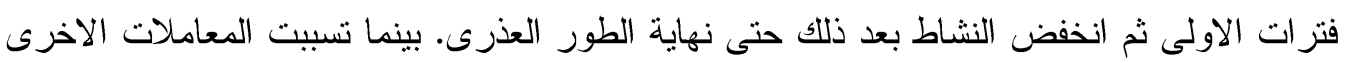
ايضا في انخفاض معنوى في نشاط إنزيم الفوسفاتيز الحامضي في معظم فترات الطور العذرى .

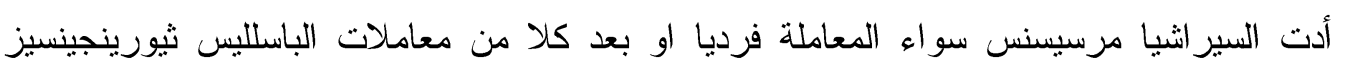

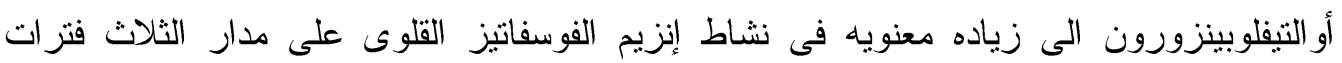
الاولى ثم انخفض النشاط بعد ذلك حتى نهاية الطور العذرى . بينما أدت المعامله بالباسلليس

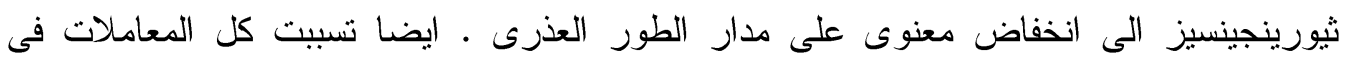
انخفاض معنوى فى المحتوي الكلي للكربوهيدرات في معظم فترات الطور العذرى. و النتائج النى تم

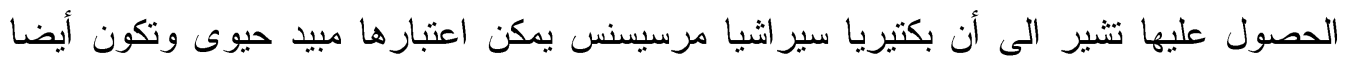

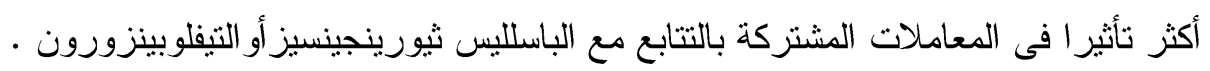

